\title{
STUDI PEMBUATAN NUGGET FUNGSIONAL DARI IKAN CAKALANG (KATSUWONUS PELAMIS L.) DENGAN EKSTRAK BUAH MENGKUDU (MORINDA CITRIFOLIA L.)
}

\section{(Studi of Making Fungsional Nugget from Skipjack Fish (Katsuwonus pelamis L.) with Noni Fruit Ekstrak (Morinda citrifolia L.)}

\author{
Jalil Genesa $^{\left.{ }^{*}\right)}$, Nandi K.Sukendar ${ }^{1)}$, dan Shinta Regia ${ }^{1)}$ \\ ${ }^{1)}$ Program Studi Ilmu dan Teknologi Pangan Departemen Teknologi Pertanian Universitas Hasanuddin \\ Makassar, Indonesia \\ *)email Penulis Korespondensi: jalilgenisa@gmail.com
}

\begin{abstract}
Nugget skipjack fish dengan ekstrak buah mengkudu adalah makanan olahan dari daging ikan. Ini digiling dengan penambahan ekstrak buah mengkudu sebagai nilai tambah (fuctional) pada produk nugget. Buah mengkudu kurang disukai oleh orang karena rasa pahit dan aromanya menyengat. Oleh karena itu, dilakukan penambahan ekstrak dari buah mengkudu pada produk olahan nugget. Penelitian ini bertujuan untuk menghasilkan produk nugget fungsional dari ikan cakalang dengan ekstrak buah mengkudu dan untuk mengetahui kandungan kimia dan fisik nugget dan kandungan alkaloid dalam nugget. Parameter yang digunakan adalah kadar air, kadar abu, kadar lemak, kadar protein, kadar karbohidrat, uji organoleptik, dan kandungan alkaloid. Desain expremental adalah Rancangan Acak Kelompok dengan 3 perlakuan dan 3 ulangan. Konten alkaloid hadir di semua perawatan. Perlakuan terbaik berdasarkan uji fisik, kimia, dan oreganoleptik nugget adalah perlakuan F3 $(60 \%$ daging fih $+7 \%$ ekstrak mengkudu $+23 \%$ pengisi $+10 \%$ air es). Hasil uji organoleptik tekstur 3,59 (suka), warna 3,48 (agak suka), aroma 3,63 (suka), dan rasa 3,77 (suka).
\end{abstract}

Keywords : Nugget, cakalang, noni, alkaloid, fungsional.

\section{ABSTRACT}

Nugget skipjack fish with noni fruit extract is a processed food from fish meat. It is milled with the addition of noni fruit extract as a value added (fuctional) on nugget products. Noni fruit is less favored by people due to the bitter taste and the aroma is sting. Therefore, it was carried out addition of extract from noni fruit on nugget processed products. This research aimed to produce functional nugget product from skipjack fish with noni fruit extract and to know chemical and physical content of nugget and alkaloids content in nugget. The parameters were water content, ash content, fat content, protein content, carbohidrate content, organoleptic test, and alkaloids content. The expremental design was Randomized Block Design with 3 treatments and 3 replications. Alkaloids content was present in all treatments. The best treatment based on physical, chemical, and oreganoleptics test of nugget was $F 3$ treatment ( $60 \%$ fih meat $+7 \%$ extract of noni $+23 \%$ filler $+10 \%$ ice water). Result of organoleptics test texture 3.59 (likes), color 3.48 (rather like), aroma 3.63 (like), and taste 3.77 (like).

Keywords :Nuggets, skipjack, noni, alkaloids, functional. 


\section{PENDAhUluan}

Indonesia merupakan negara yang kaya akan keanekaragaman hayati terutama keanekaragaman hayati lautnya. Hasil laut dari perairan Indonesia seperti ikan cakalang yang dikonsumsi dan diminati masyarakat. Ikan cakalang (Katsuwonus pelamis L.) merupakan suatu jenis ikan laut yang digemari karena mempunyai kejendalan daging yang baik terutama sebagai sumber protein. Ikan jenis ini dapat ditangkap di laut Sulawesi Selatan karena hidupnya bergerombol (Aryodhyo, 1993). Bagi masyarakat Indonesia Ikan cakalang (Katsuwonus pelamis L.) merupakan komoditi yang penting karena dapat diolah menjadi berbagai produk olahan pangan yang digemari masyarakat seperti nugget.

Buah mengkudu atau Noni (Morinda citrifolia L.) merupakan tumbuhan asli Indonesia yang lebih dikenal sebagai tanaman pekarangan untuk kebutuhan pengobatan. Hal ini dikarenakan adanya dugaan bahwa mengkudu mengandung sejumlah zat aktif yang secara sinergi menghasilkan efek yang baik bagi kesehatan tubuh seperti anti bakteri dan anti kanker.

Nugget adalah suatu bentuk produk olahan daging yang terbuat dari daging giling yang dicetak dalam bentuk potongan empat persegi dan dilapisi dengan tepung berbumbu (battered dan braded). Nugget juga dikenal sebagai makanan beku siap saji sehingga masyarakat modern saat ini sangat menggemari karena kepraktisan dalam mengonsumsi-nya. Proses pengolahan nugget pada umumnya meliputi penggilingan daging, pencampuran bumbu, pengukusan, pencetakan, pelumuran tepung, dan pembekuan.

Maka perlu dilakukan penelitian tentang pembuatan nugget yang berbahan dasar ikan cakalang dengan ekstrak buah mengkudu sehingga dihasilkan produk nugget fungsional untuk kesehatan yang dapat digemari dan diterima oleh konsumen. Selama ini sudah banyak pengolahan nugget dari ikan sehingga perlu dilakukan variasi dalam pengolahannya yaitu dengan menambahkan ekstrak buah mengkudu dalam pembuatan nugget ikan cakalang sehingga diperoleh sebagai pangan fungsional (untuk kesehatan).

Mengkudu dikenal masyarakat sebagai tanaman pekarangan yang dapat tumbuh dimana-mana dan mengganggu aromanya dari buah yang matang. Oleh karena itu, untuk memanfaatkan buah mengkudu ini dilakukan penelitian yaitu penambahan ekstrak buah mengkudu pada daging ikan cakalang dalam pembuatan nugget. Namun belum diketahui "berapa banyak konsentrasi ekstrak buah mengkudu yang dapat ditambahkan pada daging ikan cakalang dalam pembuatan nugget" sehingga dapat diterima dari segi organoleptik yaitu aroma, warna, tekstur dan rasa serta peningkatan kandungan senyawa alkaloidnya. Maka dilakukan penelitian untuk mengetahui penambahan persentase ekstrak buah mengkudu kedalam adonan daging ikan sehingga diperoleh nugget fungsional dan sesuai Standar Nasional Indonesia nugget yang dihasilkan.

\section{METODOLOGI PENELITIAN}

\subsection{Alat}

Alat yang digunakan dalam penelitian ini adalah timbangan, dandangan, pisau, grinder, blender, mixer, talenan, loyang, cetakan, kompor, pengukus, lemari pendingin, wajan, spatula, peralatan tulis.

\subsection{Bahan}

Bahan-bahan yang digunakan adalah daging ikan cakalang, air es, buah mengkudu, bawang putih, bawang merah, garam, merica, tepung tapioka, telur, susu bubuk, tepung roti, tissue roll, label, dan aluminium foil.

\subsection{Prosedur Penelitian.}

\subsubsection{Penelitian Pendahuluan}

Penelitian pendahuluan dilakukan dengan membuat ekstrak dari buah mengkudu yaitu perbandingan buah mengkudu dengan air 1:1 serta menentukan 
penambahan persentase ekstrak mengkudu $(1 \%, 2 \%, 3 \%, 4 \%, 5 \%, 6 \%, 7 \%, 8 \%, 9 \%, 10 \%)$

dan bahan pengisi /tepung tapioka $(29 \%, 28 \%, 27 \%, 26 \%, 25 \%, 24 \%, 23 \%, 22 \%, 2$

$1 \%)$ pada adonan ikan cakalang yang dapat diterima panelis berdasarkan pengujian organoleptik (aroma, warna, tekstur, dan rasa). Perlakuan terbaik yang diperoleh dijadikan acuan pada penelitian utama untuk dianalisis secara proksimat yaitu kadar air, kadar abu, kadar lemak, kadar protein, kadar karbohidrat dan alkaloid.

\subsubsection{Penelitian Utama}

Penelitian utama dilakukan dengan membuat nugget ikan cakalang berdasarkan hasil perlakuan dari penelitian pendahuluan yang disukai panelis, kemudian dilanjutkan dengan uji organoleptik dan analisa kadar air, kadar abu, dan kadar lemak, kadar protein, kadar karbohidrat, dan analisis alkaloid

\subsubsection{Prosedur kerja pembuatan nugget Ikan cakalang}

Ikan cakalang di cuci dan dibersihkan kemudian difillet. Daging ikan cakalang ditimbang sebanyak 600 gram $(60 \%)$. Ikan cakalang digiling dengan penambahan air es sebanyak $10 \%$ dan bumbu sebanyak $20 \%$ yang terdiri dari bawang putih 5\% (50 gram) , bawang merah 5\% (50 gram), merica bubuk $0,5 \%$ (5 gram), garam $1 \%(10$ gram), gula pasir 2,5\% (25 gram), susu bubuk 5\% (50 gram) dan masako $1 \%$ (10 gram) kedalam adonan. Kemudian di tambahkan bahan pengisi/ tepung tapioka dan ekstrak buah mengkudu sesuai perlakuan. Adonan yang telah tercampur di cetak kemudian dikukus selama 30 menit. Setelah adonan dikukus adonan di potongpotong dan di diamkan selama 2 menit. Kemudian dilakukan pelapisan menggunakan putih telur dan di balur dengan tepung roti. Nugget dibekukan dengan cara disimpan dalam freezer dengan suhu -10 0C selama 1 jam. Kemudian dikeluarkan dan didiamkan selama 1 menit, lalu dilakukan pengujian proksimat (kadar air, kadar abu, kadar lemak, kadar protein, kadar karbohidrat) dan analisa alkaloid. Selanjutnya, dilakukan penggorengan nugget hingga berwarna kuning keemasan untuk di uji organoleptik (Aroma, Warna, Tekstur dan Rasa).

\subsubsection{Perlakuan penelitian}

Tabel 1. Perlakuan metodologi dengan 3 kali ulangan

\begin{tabular}{lccc}
\hline \multirow{2}{*}{ Bahan } & \multicolumn{3}{c}{ Perlakuan } \\
\cline { 2 - 4 } & F1 & F2 & F3 \\
\hline $\begin{array}{l}\text { Daging Ikan Cakalang } \\
(\%)\end{array}$ & 60 & 60 & 60 \\
\hline $\begin{array}{l}\text { Ekstrak Buah Mengkudu } \\
(\%)\end{array}$ & 3 & 5 & 7 \\
\hline Tepung Tapioka (\%) & 27 & 25 & 23 \\
\hline Air Es (\%) & 10 & 10 & 10 \\
\hline TOTAL (\%) & 100 & 100 & 100 \\
\hline
\end{tabular}

*Bumbu ditambahkan 20\% dalam berat total adonan (Gambar II)

\subsubsection{Pengamatan}

Parameter yang diamati pada penelitian ini adalah sebagai berikut:

a. Analisa Kadar Air

b. Analisa Kadar Abu

c. Analisa Kadar Protein

d. Kadar Lemak

e. Kadar Karbohidrat

f. Uji Organoleptik

Tekstur, aroma, warna, dan rasa.

g. Analisa Alkaloid

Analisa alkaloid ini dilakukan dengan cara. sebanyak 2 gram sampel dihaluskan kemudian dilarutkan dalam $25 \mathrm{ml} \mathrm{H}_{2} \mathrm{SO}_{4} 2$ $\mathrm{N}$ kemudian diuji dengan pereaksi alkaloid yaitu pereaksi Wagner sebanyak 2 tetes. Hasil uji dinyatakan positif bila dengan terjadi perubahan warna atau terbentuk endapan cokelat dengan pereaksi Wagner.

\subsubsection{Analisis Data}

Data yang diperoleh dari penelitian ini diolah dengan menggunakan metode rancangan acak Kelompok dengan tiga kali ulangan. Jika terjadi perbedaan yang nyata maka di lanjut menggunakan uji Tuckey

\section{HASIL DAN PEMBAHASAN}

\subsection{Analisa Proksimat}




\subsubsection{Kadar Air}

Hasil analisa kadar air nugget fungsional dari ikan cakalang diperoleh nilai dengan kisaran 30,91-33,45 \% Hasil analisa sidik ragam terhadap kadar air nugget ikan cakalang dengan penambahan ekstrak buah mengkudu menunjukkan adanya perbedaan nyata $(\mathrm{P}>0,05)$ pada semua perlakuan sehingga dilakukan uji lanjut Tuckey. Hasil uji lanjut Tuckey menunjukkan perlakuan F1 (ekstrak 3\% + tepung tapioka $27 \%$ ) berbeda nyata dengan perlakuan F2 (ekstrak 5\% + tepung tapioka $25 \%$ ) dan berbeda nyata juga dengan F3 (ekstrak 3\% + tepung tapioka 27\%).

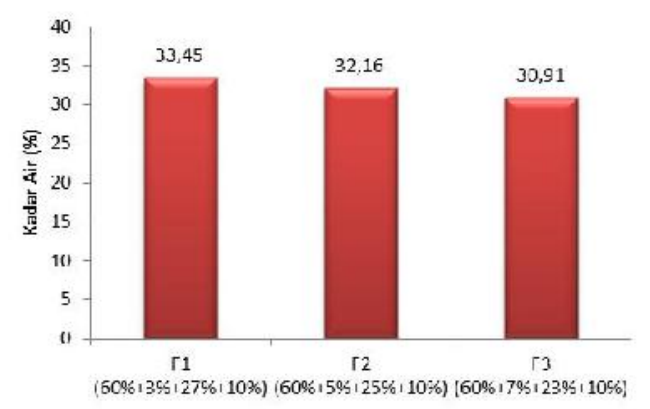

Gambar 1. Hasil Pengujian Kadar Air Nugget Ikan Cakalang

Berdasarkan Gambar 1 hasil analisa kadar air untuk setiap perlakuan berbedabeda. Hasil analisa menunjukkan bahwa kadar air tertinggi terdapat pada perlakuan F1 (ekstrak 3\% + tepung tapioka 27\%) yaitu sebesar $33,45 \%$ sedangkan kadar air terendah terdapat pada perlakuan F3 (ekstrak 7\% + tepung tapioka 23\%) yaitu sebesar 30,91\%. Hal ini diduga disebabkan oleh penambahan bahan pengisi yaitu tepung tapioka karena pada nugget yang dihasilkan semakin banyak tepung tapioka maka kandungan air semakin tinggi, dimana tapioka memiliki kandungan pati yang tinggi $(8,25 \%)$ sehingga berfungsi mengikat air dan memperkecil penyusutan. Hal ini sesuai pernyataan (Radiyati \& Agusto, 1990) bahwa kemampuan tepung tapioka dalam mengikat air akan membentuk tekstur pada produk seperti nugget. Lebih lanjut peran tapioka sebagai bahan pengisi mampu mengikat air karena memiliki gugus hidroksil dalam molekul pati yang besar sehingga semakin banyak air yang terserap, maka semakin meningkat kadar airnya (Winarno, 1997).

\subsubsection{Kadar Abu}

Hasil analisa kadar abu nugget fungsional dari ikan cakalang diperoleh nilai dengan kisaran 1,44-1,97 \%. Hasil analisa sidik ragam terhadap kadar abu nugget ikan cakalang dengan penambahan ekstrak buah mengkudu yang menunjukkan adanya perbedaan nyata $(\mathrm{P}>0,05)$ pada semua perlakuan sehingga dilakukan uji lanjut Tuckey. Hasil uji lanjut Tuckey menunjukkan perlakuan F1 (ekstrak 3\% + tepung tapioka $27 \%$ ) berbeda nyata dengan F2 (ekstrak 5\% + tepung tapioka 25\%) dan F3 (Ekstrak 7\% + tepung tapioka 23\%).

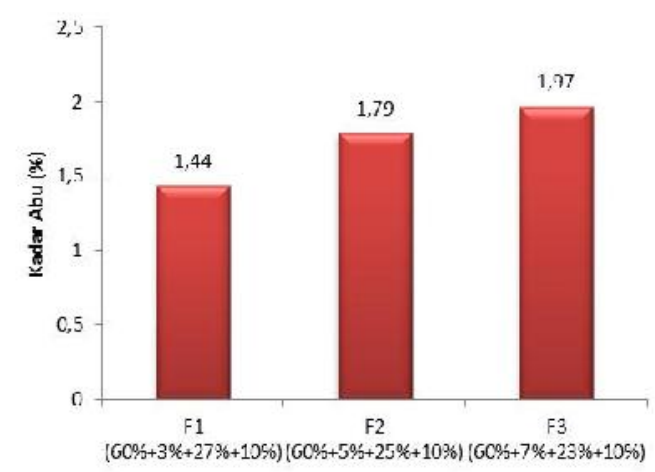

Gambar 2 Hasil Analisa Kadar Abu Nugget Ikan Cakalang

Berdasarkan gambar 2 hasil analisa kadar abu untuk setiap perlakuan berbedabeda. Hasil analisa menunjukkan bahwa kadar abu terendah terdapat pada perlakuan F1 ekstrak 3\% + tepung tapioka 27\%) yaitu sebesar $1,44 \%$ sedangkan kadar abu tertinggi terdapat pada perlakuan F3 (ekstrak $7 \%$ + tepung tapioka $23 \%$ ) yaitu sebesar $1,97 \%$. Semakin banyak ekstrak mengkudu yang ditambahkan maka kadar abu nugget semakin meningkat, hal ini diduga pada ekstrak buah mengkudu terdapat kadar abu sebesar 1,20\%. Hal ini sesuai dengan (Jurnal Litbang Pertanian, 2005) bahwa kadar abu mengkudu 1,20\% dalam 100 gram bahan. 


\subsubsection{Kadar Protein}

Hasil analisa kadar protein nugget fungsional dari ikan cakalang diperoleh nilai dengan kisaran 22,57 - 25,32\%. Hasil analisa sidik ragam terhadap kadar protein nugget ikan cakalang dengan penambahan ekstrak buah mengkudu menunjukkan adanya perbedaan nyata $(\mathrm{P}>0,05)$ pada semua perlakuan sehingga dilakukan uji lanjut Tuckey. Hasil uji lanjut tuckey menunjukkan perlakuan F1 (ekstrak 3\% + tepung tapioka $27 \%$ ) berbeda nyata dengan perlakuan $\mathrm{F} 2$ (ekstrak 5\% + tepung tapioka $25 \%$ ) dan berbeda nyata juga dengan F3 (ekstrak 7\% + tepung tapioka 23\%).

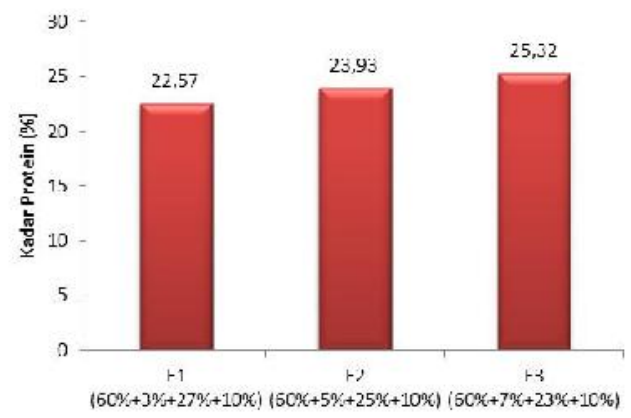

Gambar 3 Hasil Analisa Kadar Protein Nugget Ikan Cakalang

Berdasarkan Gambar 3 hasil analisa kadar protein untuk setiap perlakuan berbeda-beda. Hasil analisa menunjukkan bahwa kadar protein terendah terdapat pada perlakuan F1 (ekstrak 3\% + tepung tapioka $27 \%$ ) yaitu sebesar $22,57 \%$ sedangkan kadar protein tertinggi terdapat pada perlakuan $\mathrm{F} 3$ (ekstrak 7\% + tepung tapioka $23 \%$ ) yaitu sebesar $25,32 \%$. Semakin tinggi penambahan ekstrak mengkudu maka semakin tinggi kandungan protein nugget yang dihasilkan. Hal ini disebabkan karena protein mengkudu sebesar 2,90\% ditambahkan ke dalam protein ikan cakalang sehingga kandungan protein nugget meningkat. Hal ini sesuai pendapat (Genisa, 2000) bahwa kandungan protein pada ikan cakalang sebanyak 22,6 gr/100 gr daging.

\subsubsection{Kadar Lemak}

Hasil analisa kadar lemak nugget fungsional dari ikan cakalang diperoleh nilai dengan kisaran 3,41 5,55 \%. Hasil analisa sidik ragam terhadap kadar lemak nuget ikan cakalang dengan penambahan ekstrak buah mengkudu menunjukkan adanya perbedaan nyata $(\mathrm{P}>0,05)$ pada semua perlakuan sehingga dilakukan uji lanjut Tuckey. Hasil uji lanjut Tuckey menunjukkan perlakuan F1 (ekstrak 3\% + tepung tapioka $27 \%$ ) berbeda nyata dengan perlakuan F2 (ekstrak 5\% + tepung tapioka $2 \%$ ) dan berbeda nyata juga dengan F3 (ekstrak 7\% + tepung tapioka 23\%).

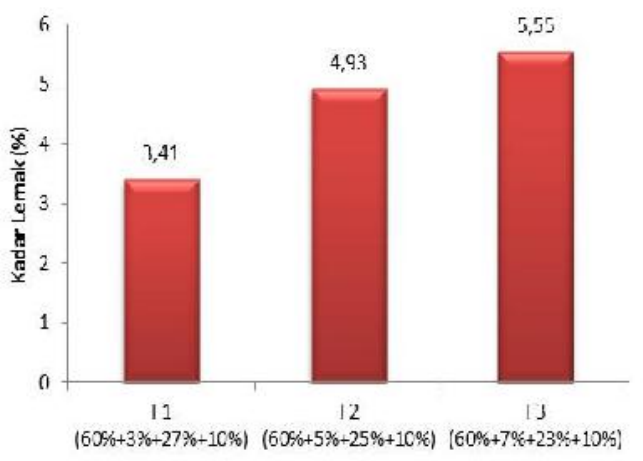

Gambar 4 Hasil Analisa Kadar Lemak Nugget Ikan Cakalang

Berdasarkan Gambar 4 hasil analisa kadar lemak untuk setiap perlakuan berbeda-beda. Hasil analisa menunjukkan bahwa kadar lemak terendah terdapat pada perlakuan F1 (ekstrak 3\% + tepung tapioka $27 \%$ ) yaitu sebesar 3,41\% sedangkan kadar lemak tertinggi terdapat pada perlakuan F3 (ekstrak $7 \%$ + tepung tapioka 23\%) yaitu sebesar $5,55 \%$. Hal ini disebabkan karena berkurangnya level persentase tepung tapioka yang ditambahkan sehingga kadar lemak menjadi meningkat, dimana kadar lemak tepung tapioka 0,40 \% (Radiyati \& Agusto, 1990) sedangkan kandungan lemak pada daging ikan cakalang yaitu $2,1 \mathrm{~g} / 100 \mathrm{~g}$ (Genisa, 2000). Selain itu kandungan lemak juga dipengaruhi oleh bahan tambahan yang digunakan seperti susu dan tepung panir.

\subsubsection{Kadar Karbohidrat}

Hasil analisa kadar karbohidrat pada nugget fungsional dari ikan cakalang diperoleh nilai dengan kisaran 33,64 $41,67 \%$. Hasilanalisa sidik ragam terhadap 
kadar karbohidrat nugget ikan cakalang dengan penambahan ekstrak buah mengkudu menunjukkan adanya perbedaan nyata $(\mathrm{P}>0,05)$ pada semua perlakuan sehingga dilakukan uji lanjut Tuckey. Hasil uji lanjut Tuckey menunjukkan perlakuan F1 (ekstrak 3\% + tepung tapioka 27\%) berbeda nyata dengan perlakuan F2 (ekstrak $5 \%$ + tepung tapioka 25\%) dan berbeda nyata juga dengan F3 (ekstrak 7\% + tepung tapioka 23\%).

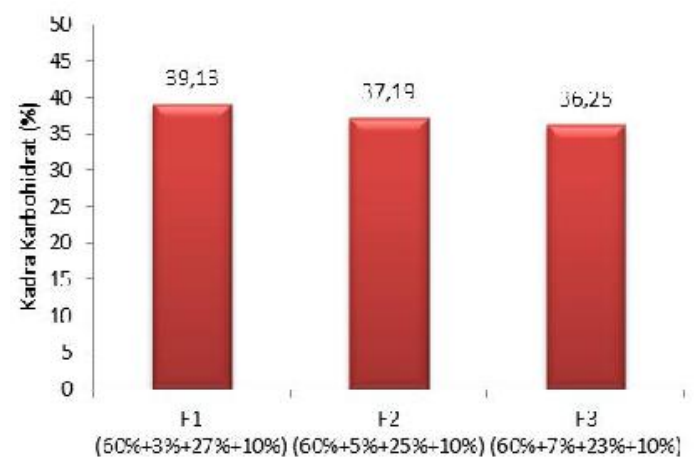

Gambar 5 Hasil Analisa Kandungan Karbohidrat Nugget Ikan Cakalang

Berdasarkan Gambar 5 hasil analisa kadar karbohidrat setiap perlakuan berbedabeda. Hasil analisa menunjukkan bahwa kadar karbohidrat tertinggi terdapat pada perlakuan F1 (ekstrak 3\% + tepung tapioka $27 \%$ ) yaitu sebesar $41,67 \%$ sedangkan kadar karbohidrat terendah terdapat pada perlakuan F3 (ekstrak 7\% + tepung tapioka $23 \%$ ) yaitu sebesar $33,64 \%$. Penurunan kadar karbohidrat pada nugget disebabkan karena berkurangnya persentase tepung tapioka yang ditambahkan dalam pembuatan nugget ikan cakalang, jumlah karbohidrat tepung tapioka $85 \%$. Dimana tepung tapioka memiliki pengaruh yang besar terhadap kadar karbohidrat nugget.

\subsection{Uji Organoleptik Nugget}

\subsubsection{Tekstur}

Hasil uji organoleptik menunjukkan rata-rata tingkat kesukaan panelis terhadap tekstur nugget fungsional dari ikan cakalang berkisar antara skala 3,47 sampai 3,64 yang mendekati skala 4 (suka) artinya panelis menyukai tekstur dari nugget ikan cakalang yang dihasilkan.

Berdasarkan analisa sidik ragam uji organoleptik terhadap tekstur nugget yang dihasilkan menunjukkan tidak adanya perbedaan nyata $(\mathrm{P}>0,05)$ pada semua perlakuan sehingga tidak dilakukan uji lanjut Tuckey.

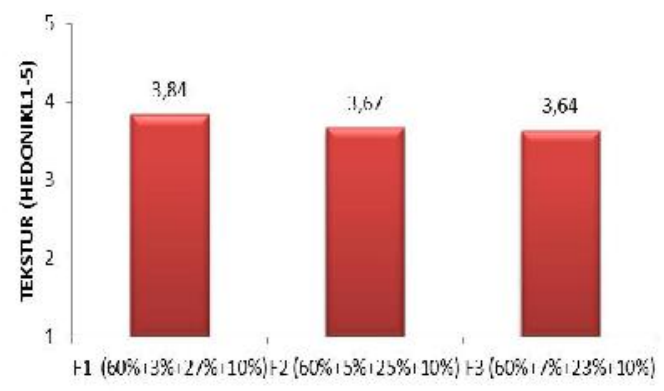

Gambar 6 Hasil Analisis Organoleptik Tingkat Kesukaan Panelis Terhadap Tekstur Nugget Ikan Cakalang

Berdasarkan Gambar 6 dapat dilihat bahwa hasil uji organoleptik tingkat kesukaan panelis terhadap tekstur dari nugget ikan cakalang yang dihasilkan berbeda-beda. Secara berturut-turut nilai tingkat kesukaan panelis terhadap tekstur yaitu ; F1 (ekstrak 3\% + tepung tapioka $27 \%$ ) memperoleh nilai 3,47, F2 (ekstrak $5 \%$ + tepung tapioka 25\%) memperoleh nilai 3,67 dan F3 (ekstrak 7\% + tepung tapioka 23\%) memperoleh nilai 3,64. Secara umum nilai tingkat kesukaan panelis terhadap tekstur dari nugget ikan cakalang mendekati skala 4 (suka). Tekstur pada nugget dipengaruhi oleh tepung tapioka yang digunakan sebagai bahan pengisi dalam pembuatan nugget. Hal ini didukung oleh (Astawan, 2009) bahwa tepung tapioka mengandung amilosa dan amilopektin yang mempengaruhi tekstur nugget yang padat dan kenyal.

\subsubsection{Warna}

Hasil uji organoleptik menunjukkan rata-rata tingkat kesukaan panelis terhadap warna nugget fungsional dari ikan cakalang berkisar antara skala 3,20 sampai 3,81 yang mendekati skala 4 (suka) artinya panelis menyukai warna dari nugget ikan cakalang yang dihasilkan. Berdasarkan hasil analisa 
sidik ragam warna dari nugget ikan cakalang dengan penambahan ekstrak buah mengkudu menunjukkan adanya perbedaan nyata $(\mathrm{P}>0,05)$ terhadap nilai warna nugget yang dihasilkan sehingga dilakukan uji lanjut Tuckey. Hasil uji lanjut Tuckey menunjukkan bahwa sampel F1 (eksrak 3\% + tepung tapioka 27\%) dan F2 (ekstrak 5\% tepung tapioka $25 \%$ ) tidak berbeda nyata tetapi berbeda nyata dengan sampel F3 (ekstrak 7\% + tepung tapioka 23\%).

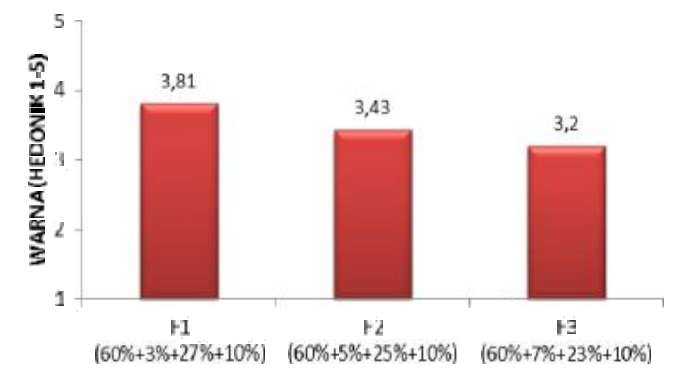

Gambar 7 Hasil Uji Organoleptik Tingkat Kesukaan Panelis Terhadap Warna Nugget Ikan Cakalang

Berdasarkan Gambar 7 dapat dilihat bahwa tingkat kesukaan panelis terhadap warna dari nugget ikan cakalang yang dihasilkan berbeda-beda. Secara berturutturut nilai tingkat kesukaan panelis terhadap warna nugget ikan cakalang yakni; F1 (ekstrak 3\% + tepung tapioka $27 \%$ ) memperoleh nilai 3,81, F2 (ekstrak $5 \%+$ tepung tapioka 25\%) memperoleh nilai 3,43 dan F3 (ekstrak 7\% + tepung tapioka 23\%) memperoleh nilai 3,20. Secara umum nilai tingkat kesukaan panelis terhadap warna nugget ikan cakalang mendekati skala 4 (suka). Warna pada nugget yang dihasilkan dipengaruhi oleh peningkatan ekstrak buah mengkudu yang ditambahkan, dimana semakin banyak ekstrak yang ditambahkan semakin gelap warna nugget yang dihasilkan. Selain itu warna nugget goreng juga dipengaruhi penggorengan dengan minyak. Selama penggorengan terjadi reaksi pencoklatan (browning) akibat pemanasan komponen yang berasal dari tepung tapioka dan tepung panir (Ketaren, 1986).

\subsubsection{Aroma}

Hasil uji organoleptik menunjukkan rata-rata tingkat kesukaan panelis terhadap aroma nugget fungsional dari ikan cakalang berkisar antara skala 3,52 sampai 3,78 mendekati skala 4 (suka) yang artinya panelis menyukai aroma dari nugget ikan cakalang yang dihasilkan. Berdasarkan analisa sidik ragam terhadap nilai organoleptik aroma dari nugget ikan cakalang menunjukkan tidak adanya perbedaan nyata $(\mathrm{P}>0,005)$ pada setiap perlakuan sehingga tidak dilakukan uji lanjut Tuckey.

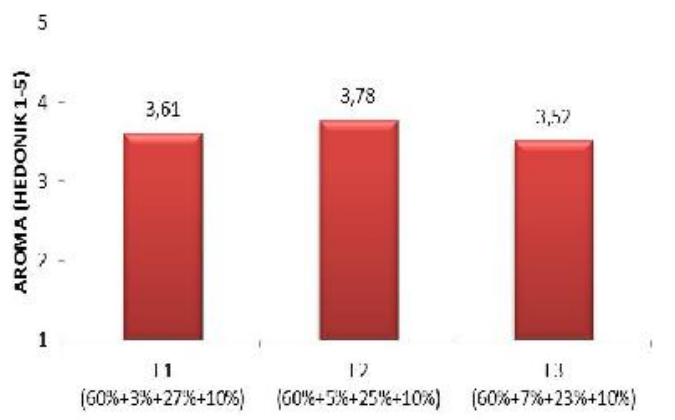

Gambar 8 Hasil Uji Organoleptik Tingkat Kesukaan Panelis Terhadap Aroma Nugget Ikan Cakalang

Berdasarkan Gambar 8 dapat dilihat bahwa tingkat kesukaan panelis terhadap aroma dari nugget ikan cakalang berbedabeda. Berturut-turut nilai tingkat kesukaan panelis terhadap aroma nugget yakni; F1 (ekstrak 3\% + tepung tapioka 27\%) memperoleh nilai 3,61, F2 (ekstrak 5\% + tepung tapioka $25 \%$ ) memperoleh nilai 3,78 dan F3 (ekstrak 7\% + tepung tapioka 23\%) memperoleh nilai 3,52 . Secara umum nilai tingkat kesukaan panelis terhadap aroma dari nugget ikan cakalang mendekati skala 4 (suka). Aroma pada nugget yang dihasilkan dipengaruhi oleh aroma bahan utama dalam pembuatan nugget yaitu ikan cakalang. Selain itu aroma pada nugget juga dipengaruhi oleh penggunaan bumbu pada pengolahan nugget dimana bumbu yang digunakan memiliki aroma khas masingmasing. Hal ini sesuai dengan (Erawaty, 2001) aroma nugget dipengaruhi oleh penambahan bumbu dan penyedap rasa seperti lada dan bawang putih, penggunaan 
bahan lain seperti susu bubuk, tepung roti dan bumbu-bumbu yang memiliki aroma khas masing-masing.

\subsubsection{Rasa}

Hasil uji organoleptik menunjukkan rata-rata tingkat kesukaan panelis terhadap aroma nugget fungsional dari ikan cakalang berkisar antara skala 3,76 sampai 3,79 mendekati skala 4 (suka) yang artinya panelis menyukai aroma dari nugget ikan cakalang yang dihasilkan. Hasil analisa sidik ragam terhadap nilai organolpetik rasa terhadap nugget yang dihasilkan menunjukkan tidak adanya perbedaan nyata yang terjadi pada setiap perlakuan sehingga tidak dilakukan uji lanjut Tuckey.

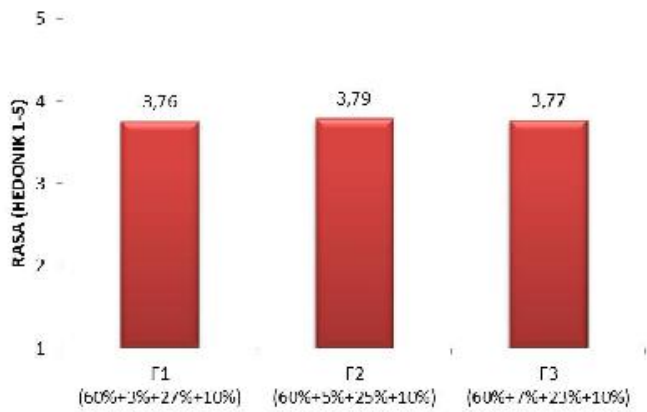

Gambar 9 Hasil Uji Organoleptik Tingkat Kesukaan Panelis Terhadap Rasa Nugget Ikan Cakalang

Berdasarkan Gambar 9 dapat dilihat bahwa tingkat kesukaan panelis terhadap rasa dari nugget ikan cakalang yang dihasilkan berbeda-beda secara berturutturut nilai tingkat kesukaan panelis terhadap rasa nugget yakni; F1 (ekstrak 3\% + tepung tapioka 27\%) memperoleh nilai 3,76, F2 (ekstrak 5\% + tepung tapioka 25\%) memperoleh nilai 3,79 dan F3 (ekstrak 7\% + tepung tapioka 23\%) memperoleh nilai 3,77 . Secara umum nilai tingkat kesukaan panelis terhadap rasa nugget ikan cakalang mendekati skala 4 (suka). Rasa pada nugget ikan cakalang yang dihasilkan dipengaruhi oleh bahan daging ikan yang digunakan, cara pemasakan terutama suhu dan lama pemasakan, serta penambahan bumbu yang meningkatkan cita rasa dalam nugget. Hal ini sesuai dengan (Buckel, Purnomo, Adini, \& Tinggi, 1985) bahwa bumbu yang ditambahkan berperan membentuk flavour yang diperkuat oleh adanya pemasakan.

\subsection{Analisa Alkaloid}

Hasil analisa kandungan alkaloid pada nugget fungsional dari ikan cakalang diperoleh tinggi endapan sebelum nugget digoreng berkisar 0,5-1,1 cm, sedangkan tinggi endapan setelah nugget digoreng berkisar 0,2-0,6.

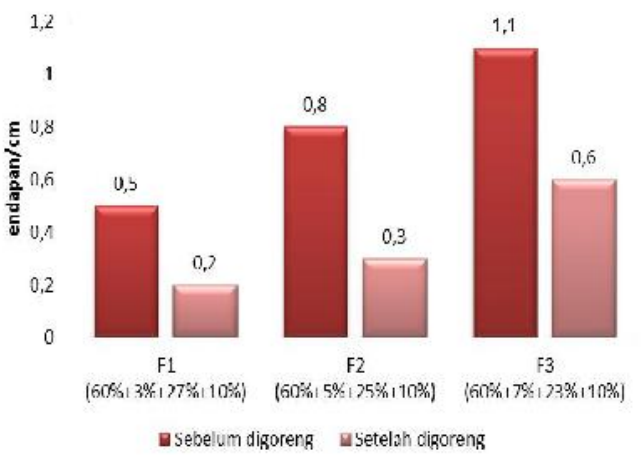

Gambar 10 Hasil Analisa Kandungan Alkaloid Nugget Ikan Cakalang

Berdasarkan Gambar 10 diatas hasil analisa kandungan alkaloid pada nugget ikan cakalang tergolong rendah dan berbeda-berbeda. Adapun tinggi endapan yang menandakan alkaloid pada setiap perlakuan sebelum nugget digoreng berturut-turut F1 (ekstrak 3\% + tepung tapioka 27\%) adalah $0,5 \mathrm{~cm}, \mathrm{~F} 2$ (ekstrak $5 \%$ + tepung tapioka $25 \%$ ) adalah $0,8 \mathrm{~cm}$, dan F3 (ekstrak 7\% + tepung tapioka 23\%) adalah $1,1 \mathrm{~cm}$. Sedangkan tinggi endapan yang menandakan alkaloid setelah nugget digoreng berturut-turut F1 (ekstrak 3\% + tepung tapioka 27\%) adalah $0,2 \mathrm{~cm}, \mathrm{~F} 2$ (ekstrak 5\% + tepung tapioka 25\%) adalah $0,3 \mathrm{~cm}$, dan F3 (ekstrak $7 \%$ + tepung tapioka $23 \%$ ) adalah $0,6 \mathrm{~cm}$.

Hal ini menunjukkan bahwa masih terdapat kandungan alkaloid pada nugget ikan cakalang yang dihasilkan baik sebelum digoreng maupun setelah digoreng, namun terjadi penurunan kandungan alkaloid pada nugget setelah digoreng. Hal ini disebabkan karena alkaloid yang merupakan senyawa metabolite sekunder cenderung mudah menguap pada suhu tinggi dan mudah teroksidasi bila tidak dikemas. Hal ini sesuai dengan (Sastrohamidjojo, 1991), 
bahwa pemanasan dapat mengurangi kadar alkaloid pada bahan makanan. Semakin tinggi suhu dan semakin lama waktu pemanasan, maka semakin banyak alkaloid yang hilang karena sifatnya yang mudah terdekomposisi oleh panas.

\section{KESIMPULAN}

Kesimpulan yang dapat diambil dari penelitian pembuatan nugget fungsional dari ikan cakalang dengan ekstrak buah mengkudu ini adalah sebagai berikut :

1. Formulasi terbaik pada nugget fungsional dari ikan cakalang dengan ekstrak buah mengkudu ditinjau dari segi fisik dan kimia yaitu formulasi pada perlakuan F3 (ekstrak mengkudu $7 \%$ + tepung tapioka 23\%) dengan perolehan nilai kadar air 30,91\%, kadar abu $1,97 \%$, kadar protein $25,32 \%$, serta kadar lemak 5,55\% (sesuai SNI nugget) dan berdasarkan organoleptik diperoleh kesimpulan bahwa parameter tekstur nugget memperoleh point 3,59 (suka), warna 3,48 (agak suka), aroma 3,63 (suka), dan rasa 3,77 (suka).

2. Kandungan alkaloid tertinggi nugget diperoleh pada perlakuan F3 (esktrak mengkudu $7 \%$ + tepung tapioka 23\%) Kandungan alkaloid pada nugget menurun setelah dilakukan penggorengan.

\section{DAFTAR PUSTAKA}

Aryodhyo. (1993). Hasil Tangkapan Cakalang Indonesia. Prosiding Seminar Implementasi Nusantara Di Bidang Perikanan. IPB-Bogor.

Astawan. (2009). Tepung tapioka Manfaat dan cara Pembuatannya. Jakarta: Penebur Swadaya.

Buckel, Purnomo, Adini, \& Tinggi, D. jendral pendidikan. (1985). Ilmu Pangan. Jakarta: Penerbit universitas Indonesia.

Erawaty. (2001). Pengaruh Bahan Pengikat, Waktu Penggorengan dan Daya Simpan terhadap Sifat Fisik dan Organoleptik Produk Nugget Ikan
Sapu-Sapu (Hyposascus pardalis). Institut Pertanian Bogor.

Genisa, jalil. (2000). Produksi Histamin Pada Ikan Cakalang (Katsuwonus pelamis L.) Selama Lepas Tangkap. universitas hasanuddin makassar.

Jurnal Litbang Pertanian. (2005). Komposisi Kimia Buah Mengkudu. Litbang Pertanian Jakarta.

Ketaren. (1986). Pengantar Minyak dan Lemak Pangan. Jakarta: Universitas Indonesia Press.

Radiyati, \& Agusto. (1990). Tepung Tapioka. BPTTG Pustlibang Fisika Terapan-LIPI, 10-13.

Sastrohamidjojo. (1991). Kromatografi. Yogyakarta: Liberty Press.

Winarno. (1997). kimia pangan dan Gizi. Jakarta: PT Gramedia Pustaka Utama. 